\title{
The Critique of Liberal Capitalism in the Light of Cardinal Stefan Wyszyński's Personalistic Concept of Socio-Economic Life
}

\section{Introduction}

Trying to provide an answer to the question about the attitude of Cardinal Wyszyński's personalistic vision of socio-economic life towards liberalism, one encounters an entire series of difficulties. Firstly, it is not clear what contemporary liberalism is in the sense of its precise definition. Intuitively, one uses the term in a correct way. In this sense, every time one wants to analyze the relation of the personalistic concept to liberalism, one must first define what content should be put under the above idea. Simultaneously, one must be aware that the word 'liberalism' is associated with something completely different in the United States and Europe. In America, however, it is a leftist view, as opposed to conservatism, advocating the use of state power to implement social justice through large-scale welfare programs. ${ }^{2}$ It is most often associated with the secular system of values, i.e., supporting abortion, euthanasia, same-sex relationships, etc. ${ }^{3}$

${ }^{1}$ Rev. Ryszard Ficek, STD, Ph.D. - priest of the diocese of Rockville Center/NY, a moral theologian and political scientist, a former lecturer of the Jordan University College in Morogoro/ Tanzania, specializing in the moral theology, church history and international relations; e-mail: rficek@optonline.net. ORCID 0000-0001-5238-6767.

${ }^{2}$ Cf. R. Scruton, Stownik myśli politycznej, Poznań 2002, pp. 190-191.

3 The governments of Bill Clinton or Barak Obama and the initiatives taken at the time on the national and international forums are an excellent example of the liberal world view in contemporary American politics. Cf. J.A. Winters, B.I. Page, Oligarchy in the United States?, "Perspectives 
Different associations evoke the word 'liberalism' on the European continent. In this sense, the European perspective is closer to the so-called 'Classical liberalism,' which refers, among other things, to the theory of the social contract, legal limitations relating to the socio-economic policy of government administration, individualism, natural rights of the individual, worldview neutrality of the state, free-market economy, etc. In this classical form, liberalism was properly 'absorbed' by all ideologies that count on the political scene. Although there are many critics of liberalism, they generally even complain about the so-called 'liberal democracy,' only a different version of liberalism, adjusted in some respect, is proposed. However, the classical understanding of liberalism is subject to dynamic changes, which means that also in the Old Continent, it is associated more and more often with ideological liberalism, that is, with a left-wing ideology.

Liberalism emerged based on Christianity, and it would be difficult to conceive outside of Western culture. It means that it contains many ideas derived from Christianity. However, some of its 'own' elements also appeared to contest some historical forms of organization of the Christian world. ${ }^{4}$ Central to liberalism is its moral and universalistic character. However, it seems that only after highlighting the difficulties in defining liberalism and emphasizing its dynamic nature one can begin to reflect on the personalistic concept of Cardinal Wyszyński regarding this doctrine.

\section{The Idea of Liberal Capitalism: the Origins, Definition, and Specifics of the Concept}

Classic liberal capitalism seemed to be the apotheosis of economic freedom, understood as freedom in economic activity, unrestricted individual entrepreneurship, and freedom of exchange aimed at maximizing profits. In that sense, it has been identified with the economic efficiency and prosperity that societies can achieve through economic freedom, hard work, and competition. Of course,

on Politics" 7 (2009) 4, pp. 731-751; L.R. Jacobs, D.S. King, Varieties of Obamaism: Structure, Agency, and the Obama Presidency, "Perspectives on Politics" 10 (2010) 3, pp. 793-802.

${ }^{4}$ Nevertheless, in the tradition of the Catholic Church, liberalism was not very well associated. After all, the liberal was Denis Diderot - philosopher, encyclopedist, as well as one of the prominent ideologues of the Enlightenment period - who in his work Eleuthéromanes announced to the world, paraphrasing, that 'it will not be good as long as the last king will not be hung on the bowels of the last priest.' (J. Varloot, Vrai ou faux ami? L'original des Eleuthéromanes, "Recherches sur Diderot et sur l'Encyclopédie" 10 (1991) 9). However, apart from the French, there was also the Anglo-Scottish Enlightenment, referring to the classical Greco-Roman and Judeo-Christian tradition, whose representatives were not - like Diderot - atheists, but at least deists. But they were also subjects of the British king, the head of the Anglican Church, which in Rome — by definition - made them homegrown representatives promoting 'suspect' philosophical concepts. 
the current of liberalism is not homogeneous in itself. Moreover, it has clearly changed its face over the past two hundred years. This account applies both to philosophical and social liberalism, as well as to economic liberalism, which has found its concrete expression in classical capitalism and its modern variants (including neo-capitalism). However, the essential flagships with which this system is intuitively associated are freedom, equality, property, laissez-faire, freedom of action, freedom for enterprises, freedom of exchange, free movement of capital, as well as people and goods, free market, limitation of state intervention, etc. ${ }^{5}$

Nevertheless, liberal capitalism delivers a 'mixed bag of results' and also has serious disadvantages - part of the difficulty in identifying these problems in the ambiguity mentioned above in the definition of capitalism. Moreover, classical capitalism tends to devalue the human person to the marginal product of his labor and, thereby, distorts the proper theological end of economics as serving humanity's needs. Besides, methodological individualism is directly opposed to the principle of solidarity and may lead to a de-emphasis on the communal aspect of the Church. The tendency of large corporations to put out of place local initiatives may cause a violation of the principle of subsidiarity. Thus, classical capitalism tends to devalue the human person to the marginal product of his labor and, thereby, distorts the proper theological end of economics as serving the needs of humanity. Besides, methodological individualism is directly opposed to the principle of solidarity. It may also lead to a de-emphasis on the communal aspect of the Church. Furthermore, large corporations tend to displace local enterprises. It may not be a fundamental feature of capitalism, but it may threaten local economic initiatives and violate the principle of subsidiarity. ${ }^{6}$

Consequently, fundamental as well as trendy ideas of liberalism such as freedom, individualism, evolution, etc., rapidly embraced new areas of human existence: the worldview, social, political and state, economic, spiritual, and cultural, as well as religious or ecclesiastical as well as political spheres. However, liberal views crystallized to the fullest and then found their application in political and economic life. Thus, one may refer to Elaine Sternberg, who defines

${ }^{5}$ Referring to supporters of extremely liberal concepts, Wyszyński sarcastically stated: 'The freedom to get rich is the highest economic law. Everything should serve as protection for man in his quest for personal well-being; even religion and the state should protect his worldly interests. Man is homo oeconomicus. Nothing else! Everything else is just a minor addition to life and should serve one purpose. Twin - is "human material", placed on an equal footing with the raw material in a series of production costs; co-workers - it's the amount of work, it's a week's wage or a pay level, it's "physical strength", it's an officer. And nothing more! Nothing else binds us to him' (id., Miłość i sprawiedliwość społeczna. Rozważania społeczne, Poznań 1993, p. 46).

${ }^{6}$ Cf. R. Ficek, Christians in Socio-Political Life: An Applied Analysis of the Theological Anthropology of Cardinal Stefan Wyszyński, Primate of Poland, Torun 2020, pp. 106-107. 
contemporary capitalism as an economic system characterized by private property, free-market pricing, and the absence of coercion. ${ }^{7}$ Nevertheless, the above definition's vagueness leads to many ambiguities, especially in the context of the historical evolution of the concept of "capitalism."

Considering the genesis of the concept, Max Weber looks for the origins of the entire capitalist system in the sixteenth-century transformations resulting from the Protestant Reformation spirit. Thus, the author of Die Protestantische Ethik und der Geist des Kapitalismus pays particular attention to the Lutheran concept of vocation, as well as to the Calvinist doctrine of double predestination. According to Weber, the Lutheran doctrine of salvation obtained only through faith (sola fide) stands in opposition to the Catholic concept of redemption achieved through a virtuous life and good deeds.

Moreover, Protestant's rejection of salvation through the sacramental dimension of the Christian life (in particular, the sacrament of Penance and Reconciliation) and the adoption of the concept of double predisposition forced the faithful to seek alternative 'signs' confirming their status as elected and destined for eternal life with God. According to Weber, the 'tangible' sign of 'belonging to the group of the chosen ones' was 'success' in earthly life, understood as a prudent and hard-working life ad maiorem Dei gloriam. ${ }^{9}$

Obviously, modern market economy systems based on liberalism encompass a wide variety of schools and competing concepts. They include, among others: 'Chicago school of economics,' 'Austrian school,' representatives of 'Public Choice Theorists,' 'institutional economists,' monetarists, ${ }^{10}$ representatives

7 Cf. E. Sternberg, Defining Capitalism, "Economic Affaires" 35 (2015) 3, p. 385.

${ }^{8}$ Liberalism, understood as a socio-political and economic system, is not homogeneous. Besides, it has changed its face over the last two hundred years. This statement refers to both philosophical and social liberalism, as well as to economic liberalism, which has found its concrete expression in classical capitalism and its contemporary variants (e.g. in neo-capitalism). The most popular banner slogans that systems had been intuitively associated with were: freedom, equality, ownership, laissez-faire, freedom of action, freedom for enterprises, freedom of exchange, free movement of capital, people and goods, free market, restriction of state intervention, etc. The liberal ideas - such as freedom, individualism, and evolution - quickly embraced new spheres of human existence: the worldview, the social, the political-state, the economic, the spiritual-cultural, and the denominational or ecclesiastical-political structures. However, the liberal views were those which had been most fully crystallized. They then found their application in political and economic life (cf. E. Altvater, Kapitalismus, Zur Bestimmung, Abgrenzung und Dynamik einer geschichtlichen Formation, "Erwägen Wissen Ethik" 3 (2002), pp. 281-292).

9 Cf. M. Weber, The Protestant Ethic and the Spirit of Capitalism, New York 2003, pp. 111112.

${ }^{10}$ Cf. J.K. Galbraith, Das Scheitern des Monetarismus. Von den Theorien Milton Friedmans zur Weltfinanzkrise, "Blätter für deutsche und internationale Politik" 9 (2008), pp. 69-80. 
of 'Keynesian,' 'Georgism,' distributionism, ${ }^{11}$ socialism, ${ }^{12}$ as well as other economic concepts related to the above ideas. Nevertheless, in common understanding, political and economic liberalism issues are understood in the broad sense in terms of 'neoclassical theory.'

Thus, the concept of the social market economy functioning in many Western European countries is a combination of a capitalist economic system based on the assumptions of a free market and the principles of social and social security shaping and fair conditioning competition both within the market and throughout the welfare state. This system is also referred to as the "coordinated market economy. ${ }^{13}$ Initially, the concept of a social market economy was launched and implemented in West Germany by the CDU 'Christian Democrats' under the rule of Konrad Adenauer. In this context, the social market economy concept was designed as the third path between the liberal laissez-faire economy and the centrally steered socialist economy. ${ }^{14}$ Therefore, it was rooted in ordoliberalism, social-democratic ideas, the political ideology of Christian democracy, and above all, in Christian ethical thought. ${ }^{15}$

In other words, they refer to classical capitalist ideas, usually associated with the concepts of Adam Smith, David Ricardo, or other ideologues of the system from the $19^{\text {th }}$ and early $20^{\text {th }}$ centuries. When presenting the above ideas in the light of current political and economic conditions, the fundamental concepts of Christianity refer to the thought of St. Thomas of Aquinas or Aristotle. It is crucial in the context of such vital issues as the concept of social justice or the idea of social solidarity. ${ }^{16}$ As Cardinal Wyszyński put it:

${ }^{11}$ Cf. D.W. Cooney, Distributism Basics: A Brief Introduction, https://ethikapolitika.org/ 2014/08/08/distributism/ [accessed: 9.12.2019].

${ }_{12}$ Cf. P. Wilberg, Deep Socialism: A New Manifesto of Marxist Ethics and Economics, London 2003, pp. 3-38; R. Pipes, Property and Freedom, New York 2000, pp. 209-281.

${ }_{13}$ Cf. J. Koppstein, M.I. Lichbach, Comparative Politics: Interests, Identities, and Institutions in a Changing Global Order, Cambridge 2005, p. 156.

${ }^{14}$ Cf. W. Abelshauser, Deutsche Wirtschaftsgeschichte seit 1945, Hamburg 2004, pp. 89-93.

${ }_{15}$ As Arthur Brooks, the president of the American Enterprise Institute (a conservative public policy advocacy group), emphasized: It turns out that between 1970 and 2010, the worst poverty in the world - people who live on one dollar a day or less - that has decreased by 80 percent. You never hear about that. It is the most outstanding achievement in human history. It is the best anti-poverty measure ever invented. Cf. M.J. Perry, It's the Greatest Achievement in Human History, and One You Probably Never Heard About, American Enterprise Institute, November 3, 2014, www.aei.org/publication/greatest — achievement-human-history-one-probably-never-heard/ [accessed: 3.4.2019].

${ }^{16}$ Cf. G. Small, Connecting Economics to Theology, "Solidarity: The Journal of Catholic Social Thought and Secular Ethics" 1 (2011) 1, pp. 1-2. 
Man needs economics not only because God gave the earth to man so that he might have dominion over it also, because man's involvement in economics shapes human being. ${ }^{17}$ [Consequently], [...] the economic system should, first and foremost, correspond to the human person, his own and social, as well as temporal and ultimate goals. ${ }^{18}$

\section{Liberal Capitalism and the Personalistic Notion of Socio-Economic Life}

For centuries, western political thought and practice have been severing itself from one of its richest and morally ennobling insights. Therefore, the entire political, economic, and social order should be centered around the human person. Although easily demonstrable, this insight is not commonly recognized today. Ideologies left and right claim to be in favor of the 'individual,' and few have come to understand the fundamental difference between this 'individual' and the real human person. The concept of the individual is distinctively modern and abstract. Even though attempting to build on the moral capital accumulated by its predecessor, the person, it is different in kind. The person is concrete, historically, and culturally situated, and a member of a specific community. The modern individual is detached from all these connections.

17 S. Wyszyński, Kościót jest najlepszym sprzymierzeńcem waszych dążé. Do NSZZ , Solidarność” regionu Wielkopolska (Gniezno 4.02.1981) [in:] Do „Solidarności”, Warszawa 1996, p. 50. Suppose we were to choose just a few sentences characterizing John Paul II's attitude towards the economic liberalism. In that case, we should probably begin with the approval of the 'free market' expressed in the encyclical Centesimus annus, issued immediately after the collapse of the communist system. 'It would appear that, on the level of individual nations and of international relations, the free market is the most efficient instrument for utilizing resources and effectively responding to needs' (Centesimus annus, 34). Nevertheless, this opinion was accompanied by the statement: 'The Church acknowledges the legitimate role of profit as an indication that a business is functioning well. When a firm makes a profit, this means that productive factors have been properly employed and corresponding human needs have been duly satisfied' (ibid., 35).

${ }^{18}$ Ibid. S. Wyszyński, Miłość i sprawiedliwość..., p. 407. The above annotations were quite a clear indication of the desired direction of changes after abandoning the 'centrally controlled economy' model. However, the approval of the free market is not unconditional. Firstly, the Pope emphasizes that while the market is an effective tool to meet requirements, it applies only to some human needs, namely those that can be paid for and only those goods that are 'salable.' It means that in areas such as the satisfaction of basic human needs, access to cultural goods, knowledge, or education, the free market's principles must be supplemented somehow. Above the logic of the exchange of equivalent values - following the principle of exchangeable justice - there is justice, thanks to which man receives from society all that is due to him because of human dignity, i.e., because he is a human being. 'Inseparable from that required "something" is the possibility to survive and, at the same time, to make an active contribution to the common good of humanity' (John Paul II, Centesimus annus, 34). This thesis is a consequence of the accepted principle of the universal destination of all created goods (cf. ibid., 30). 
However, disregarding the complicated historical reality, it must be admitted that liberal capitalism has contributed to creating a diverse socio-political and economic system in which both positive and negative effects can be seen. In this context, therefore, Cardinal Wyszyński states:

Today, after years of various hardships and efforts, we see that it is not enough to 'save' only the economy and production because new situations are emerging, showing new tasks. Modern development no longer follows the question line: what do you have, what do you have, and what do you lack? Instead, we should ask: who are you? What is your value? What do you bring to the family, work, social, economic, and religious life? A new problem emerges, not so much of one system or another, but of a human being. The point is that a man, to whom the organization of economic life and production technology helps to master the world, should not be enslaved by the conditions of dependent labor. ${ }^{19}$

Concerning the above statement, many difficulties in the proper diagnosis of problems relating to liberal capitalism are associated with defining the above concept as a political and economic system. Moreover, in the traditional version, classical capitalism tended to present the human person as a kind of 'by-product' of human labor and - as a consequence - a distortion of the philosophical and theological perspective, i.e., the primary goals that economics is to serve in the context of the needs and requirements of the human person. ${ }^{20}$ On the other hand,

19 S. Wyszyński, Duch Ewangelii w organizacji życia społeczno-zawodowego i publicznego $w$ Polsce. Do wiernych $w$ archikatedrze warszawskiej 6.01.1978 [in:] Nauczanie spoteczne 19461981, red. M. Płaskacz i in., Warszawa 1990, p. 802. Personalism is a different way of looking at life and 'doing polities.' Wyszyński's teaching emphasized that human history is not to do with progress or material success, but rather that Christ is at the center of human history in his Incarnation and his Redemption of the world. The human person, made in the image of God, is intended 'to participate with God in the building of the New Creation'. Cf. Ibid. In a similar vein speaks John Paul II. In his opinion, the most priceless value in the capitalist economic system is a man. 'It is possible for the financial accounts to be in order, and yet for the people - who make up the firm's most valuable asset — to be humiliated and their dignity offended. Besides being morally inadmissible, this will eventually have negative repercussions on the firm's economic efficiency. In fact, the purpose of a business firm is not simply to make a profit, but is to be found in its very existence as a community of persons who in various ways are endeavouring to satisfy their basic needs, and who form a particular group at the service of the whole of society. Profit is a regulator of the life of a business, but it is not the only one; other human and moral factors must also be considered which, in the long term, are at least equally important for the life of a business' (Centesimus annus, 35).

${ }^{20}$ Referring to enthusiasts of liberal concepts, Wyszyński states: 'Some proclaim man as a god for himself. They proliferate [human] laws at the expense of God himself and the weaker fellowman, at the cost of society and the state. Everything is to bow to man. There are no restrictions. They subject everything to the highest and irrevocable judgment of man: they proclaim his moral 
extreme individualism opposes the principle of solidarity and directly affects the community dimension of the Church's teaching. An important example of this is the activity of large industrial and commercial corporations, which not only poses a threat to local economic initiatives but also undermines the principle of subsidiarity. ${ }^{21}$

In other words, 'classical capitalism' has often tended to devalue the human person only to the dimension of a kind of product: the product of the labor process. In this sense, it distorted and misrepresented the theological significance of economic activity understood as a service to satisfy people and communities' needs. Additionally, extreme methodological individualism directly opposes the principle of solidarity. It may also lead as well to a depreciation of the community dimension of involvement in socio-political life. In practice, large corporations often seek to marginalize - and consequently — eliminate local economic enterprises. Admittedly, this may not be an essential feature of capitalism. Nevertheless, efforts to monopolize the market pose a severe threat to local economic initiatives, as well as the principle of subsidiarity. ${ }^{22}$

Therefore, the Church's social teaching emphasizes the need to show the importance and co-relationship between social justice and economic justice. The

freedom, freedom from all social obligations. They only recognize private morality for personal use. Man can do what he likes - morality is his own thing. They do likewise with God. Religion is also a private thing of man. Perfection and striving for God have no social significance. The supreme goal of man is his temporal happiness. For this purpose, you can strive for all the ways, because here, no moral principles bind' (Miłość i sprawiedliwość..., p. 46).

${ }^{21}$ Pope John Paul II, in his encyclical Laborem Exercens distinguished the so-called 'Early capitalism' from the so-called 'Reformed capitalism'. Overall, this corresponds to the distinction between so-called the 'economy of early capitalism' and the economic concept of Keynes. In other words, 'the error of primitive capitalism can repeat itself wherever man is treated, in a way, on an equal footing with the entire set of material means of production, as a tool, and not - as it corresponds to the proper dignity of his work - as the subject and agent, and through the same as the appropriate purpose of the entire production process' (ibid., 7).

${ }^{22}$ As John Paul II put it: 'In this sense, it is right to speak of a struggle against an economic system, if the latter is understood as a method of upholding the absolute predominance of capital, the possession of the means of production and of the land, in contrast to the free and personal nature of human work. In the struggle against such a system, what is being proposed as an alternative is not the socialist system, which in fact turns out to be State capitalism, but rather a society of free work, of enterprise and of participation. Such a society is not directed against the market, but demands that the market be appropriately controlled by the forces of society and by the State, so as to guarantee that the basic needs of the whole of society are satisfied' (Centesimus annus, 35). Moreover, 'the purpose of a business firm is not simply to make a profit, but is to be found in its very existence as a community of persons who in various ways are endeavouring to satisfy their basic needs, and who form a particular group at the service of the whole of society. Profit is a regulator of the life of a business, but it is not the only one; other human and moral factors must also be considered which, in the long term, are at least equally important for the life of a business' (ibid., 35). 
concept of social justice is deeply rooted in the idea of human dignity, which in turn, as well as contemporary political and economic relations that determine the notion of economic justice. As John Perkins emphasizes, an essential factor involved in the economy is part of the modern concept of justice in the economy, but very often violates the idea of social justice. In his opinion, the current 'predatory' model of the market economy shows that even without considering the basic principles of Catholic social teaching, society is aware of the injustice. ${ }^{23}$ Thus, it is essential to make appropriate changes to the liberal economic system and to make people realize that many of the achievements of the so-called liberal 'market economy' is the result of non-economic factors. Moreover, economics, as a scientific discipline, needs an axiology (moral values) orientation. It requires a valuation of the dignity of the essential subject of economic activity, which is the human person, and not the homo oeconomicus. ${ }^{24}$

Hence, the neoclassical concept of capitalist economics presents the standardized approaches to the free market, trade, price formation, etc., as appropriate economic efficiency tools. However, it must be admitted that many other economic concepts differentiate their strategy of action, taking into account specific conditions. Nevertheless, most of them share the view that economics as a science is primarily based on empirical observations. Its methodology refers to contemporary social sciences based on the rules taken from the natural sciences. However, in the opinion of many economics representatives, this type of science is characterized by far-reaching autonomy. It does not have to take into account the moral aspect (axiological autonomy). It does not also consider the fact that economics relates primarily to the human person's broadly understood activity.

Therefore, from the Christian point of view, as Primate Wyszyński emphasizes: '[...] man is obliged to cooperate in God's government, to collaborate in God's creative activity. [...] It is the right way to heaven for all who have. For one goes to heaven through earthly goods: not by loving them, but by using them correctly'. ${ }^{25}$ As a result,

${ }^{23}$ Cf. H. Perkins, Confession of an Economic Hit Man, San Francisco 2004.

${ }^{24}$ Cf. A.K. Sen, Poverty and Famines: An Essay on Entitlement and Deprivation, Oxford 1981. Cardinal Wyszyński undoubtedly addressed this reality. He repeatedly spoke about the 'social disposition' that would foster just socio-political as well as economic transformation. In his opinion, the social outlook should be based on the subject matter of the personalistic system, which aims to convert the human heart according to a Christian set of values. In this way, only morally transformed and - thus - personally mature people can become the right subject of all sociopolitical structures, as well as a proper base for the appropriate shaping of the 'common good' of all society. Cf. S. Wyszyński, Czas to miłość. Podczas uroczystości Wniebowzięcia Matki Bożej (Jasna Góra, 15.08.1979) [in:] Nauczanie spoleczne..., pp. 889-891.

${ }^{25}$ S. Wyszyński, Miłość i sprawiedliwość..., pp. 404-405. As Wyszyński emphasized: 'The fact that the communist states based the economy on the capitalist system of work is simply the result of a derivative relationship between collectivism and capitalism. It is their original sin. Both 
[...] every person, both the entrepreneur and the organizer of the workshop, and the worker become God's collaborators in ruling over the earth. God equips man with appropriate abilities, makes him a co-worker, moreover - makes him the head of creation. Man is, as it were, the 'priest of creation' and hence all his dignity in economic life. Through his work, a man who cooperates with God raises everything and offers it to God. ${ }^{26}$

Therefore, Catholic social teaching postulates the need to include free-market economic activity in a broader moral context. However, this requires the market game participants to adopt objective ethical principles defining the ethicality of specific actions in the field of economy and the spirit of solidarity and responsibility for the common good. ${ }^{27}$ 'Perhaps morality and economy have never stood as close together as they are today. We can see it in this experiment of hard toil and extra-strong work, which disintegrated social life, and the disintegration of moral life caused by this style of work and organization of work. ${ }^{28}$

systems originate from the same materialistic philosophy. Both practically proclaim the primacy of things over a person, and both do not successfully defend a man against the demon of technocratic. Moreover, it gave the man to the service of the economy against the rights of the human person' (id. Problem pracy górników w Polsce. List do księdza biskupa Herberta Bednorza (2.02.1978) [in:] Nauczanie spoteczne ..., pp. 810-811).

${ }^{26}$ Id., Miłość $i$ sprawiedliwość..., p. 407. The fall of 'real socialism' and the disgrace of communist ideology do not induce John Paul II to recognize that only the liberal model of the economy and liberal ideology remained on the battlefield. 'We have seen that it is unacceptable to say that the defeat of so-called "Real Socialism" leaves capitalism as the only model of economic organization.' (Centesimus annus, 35). The thesis about the end of history does not belong to the intellectual domain of John Paul II's ideas. 'The crisis of Marxism does not rid the world of the situations of injustice and oppression which Marxism itself exploited and on which it fed. To those who are searching today for a new and authentic theory and praxis of liberation, the Church offers not only her social doctrine and, in general, her teaching about the human person redeemed in Christ, but also her concrete commitment and material assistance in the struggle against marginalization and suffering' (ibid., 26). It could be said that the collapse of communism caused the Pope to be bolder in his criticism of the Western model of capitalism, which is, in a sense, as 'materialistic' as communist materialism. The phenomenon of consumerism has its source not only in faulty attitudes of consumers to material goods but also in the conscious creation of artificial needs and the production of consumption habits and lifestyles that are objectively wicked or harmful to the physical and spiritual health of a person (cf. ibid., 29 and 36). According to the Pope, this is where Marxism and capitalism meet together (cf. ibid., 20).

${ }^{27}$ Cf. G. Small, Property, Commerce and Living God's Will, "Journal of Interdisciplinary Studies" 16 (2004) 1-2, pp. 157-172.

${ }^{28}$ S. Wyszyński, Wyzwalanie wspótczesnych niewolników. Do dziekanów archidiecezji warszawskiej 24. 09. 1980 [in:] Nauczanie spoleczne..., p. 958; Ł. Czuma, Dysproporcje rozwoju gospodarczego i problem ich likwidacji, "Zeszyty Naukowe KUL" 11 (1968) 2, pp. 53-67; S. Lombardini, Ungleichheit in der Weltwirtschaftsordnung (Preise, Protektionismus, Wachstumsprozesse), “Concilium” 16 (1980) 12, pp. 676-681. 


\section{The Personalistic Concept of Socio-Economic Life as a Deliberation of the Truth about Man}

Consequently, the Christian concept of socio-economic life requires revealing the full truth about man, which invariably reminds us that

$[\ldots]$ he holds precedence over the created world. In the hierarchy of values emphasizes Wyszyński - at the head is God the Father, Creator of heaven and earth, then, man as the fruit of God's love, and then, the material world is given to man to subdue the earth. Hence the obligations for man to properly discern in this fundamental divine order and to refine the perfection of the earth and its creations into God's program. ${ }^{29}$ At all levels of the human structure, starting from the nature of the human personality, through his family life, social, professional, national, state, international, and human coexistence. They are constantly repeated at all modern construction levels: truth, freedom, justice, and love. Only at this price, humanity can develop themselves normally, that is, make progress. ${ }^{30}$

Thus, justice in the economy fits into the perspective of love, as do the various forms of social and economic involvement, which appear not only as a gift and a task but, above all, as a manifestation of love.

${ }^{29}$ S. Wyszyński, Najważniejsza wartościa na świecie jest człowiek. Do delegacji NSZZ „, Solidarność” Region Mazowsze 19.10.1980 [in:] Nauczanie spoleczne..., p. 962. As Wyszyński put it: 'Created in the image and likeness of God, almost smaller than angels, crowned with the glory and honor by the Creator, a man stands between earth and heaven as the king and ruler of the earth and as heir to heaven. In this approach, the value of the human person is determined not only by his Divine origin and likeness to God but also is shown in the context of the Trinitarian mystery: in the context of the mystery of the Incarnation and Redemption made by Jesus Christ' (id., O katolickiej woli życia. List pasterski na Wielkanoc 1947 [in:] Nauczanie spoleczne..., p. 34).

${ }^{30}$ Id., In principio, In principio erat Verbum... W 600-lecie powstania Uniwersytetu Jagiellońskiego. Kraków - kościót św. Anny 5.09.1964 [in:] id., Z rozważań nad kultura ojczysta, Warszawa-Poznań 1979, p. 58. However, the words of John Paul II caused great consternation: 'Supporters of capitalism in its extreme form tend to close their eyes to what communism has done well: its fight against unemployment, its concern for the poor. [...] In communism, there was a concern for the community. At the same time, capitalism is rather individualistic' (Jan Pawel II, Nauczanie społeczne kościoła integralna czesścia jego misji (wywiady), Rzym 1996, pp. 102-103). In fact, the thought is not surprising in the pope's mouth and refers to his belief that communism was successful in the minds of workers because it was a response to a kind of 'wild and depraved capitalism' that is also called ultra-liberal capitalism (cf. ibid., p. 100). The awareness of this fact caused at the very beginning of the pontificate not only the development of two documents on specific trends in liberation theology but also the 'shifting' of the Latin American Church to the path of 'preferential option for the poor.' 
Whoever thinks that truth, freedom, and justice are sufficient for a man who does not understand a man. Those who think that these three powers can fulfill the essence of human endeavor are wrong. There is another power in man: it is the power of love. It takes up so much space in human nature that the forces of truth, freedom, and justice are merely the threshold at the door from which we can experience the reality of love. ${ }^{31}$

Many contemporary critics of liberal concepts emphasize that the capitalist economic system is fundamentally incompatible with modern economic programs and the 'planet-wide' ecosystem. In their opinion, the world economy is based on limited material resources. Nevertheless, the capitalist economic model is based on a paradigm of 'infinite' economic growth. Therefore, if nature's laws cannot be changed, the approach to fundamental issues related to the world economy's functioning system must be thoroughly revised. ${ }^{32}$ In practice, this means the debunking of the most critical 'myths' embedded in modern economic and political systems.

Thus, Cardinal Wyszyński stated:

I cannot agree to the traditional division into capitalist and collectivist schools. When it comes to these two directions: capitalist and collectivist, I believe that there is no difference; everything is on one side. However, the proletariat is not yet liberated [...]. Man is not respected yet. He is still a slave to the state to matter again. But it does not change the form of things to whom it is a slave: gold, matter or the state. ${ }^{33}$

The specificity of the Christian life is expressed primarily in fundamental moral obligations, especially in all-embracing love. Only in this context can we speak of particular attitudes, rights, or moral norms — including Christian

${ }^{31}$ S. Wyszyński, Kamienie węgielne budowania na górach świętych (Jasna Góra 2. 11. 1956) [in:] Wielka Nowenna Tysiaclecia, Paryż 1962, 41. 'Today — continues Primate Wyszyński after years of various hardships and efforts, we notice that it is not enough to "save" only the economy and production because new situations are emerging, showing new tasks. Modern development no longer follows the question line: what do you have, what do you have, and what do you lack? Instead, we ask: who are you? What is your value? What do you bring to the family, work, social, economic, and religious life? A new problem emerges - not so much of one system or another, but of a human being. The point is that a man, to whom the organization of economic life and production technology helps to master the world, should not be enslaved by the conditions of dependent labor' (id., Duch Ewangelii..., p. 803).

32 Cf. Francis, Evangelii Gaudium (November 24, 2013), 55.

${ }_{33}$ S. Wyszyński, Moc żywej wiary w ciężkiej sytuacji Kościoła. Do duchowieństwa w Gdańsku 23.11.1960 [in:] Nauczanie spoleczne..., p. 166. 
involvement in social and economic life - as a concretization of the moral life flowing from faith. ${ }^{34}$

Through faith, love, and grace, a community is created, a community of Christ a Church in which responsibility for the faith received and love is born. Responsibility for the faith and love of others is also born. Through faith and love, we become capable of confessing Christ to people and of social love. ${ }^{35}$ If a man were aware that the essence of the whole thing is to love one's neighbor as himself, it would be easier to improve mutual relations, establish principles of distributive, social or any other justice. The law of love and its embodiment - social justice - are inspired by Christian hope. ${ }^{36}$

In a socio-economic reality, where one entity of economic activity can use without any fear of repercussions and the response of the other weaker party, and yet chooses the option of fair cooperation for both parties, is a kind gift, especially for the more vulnerable and unprivileged party. In this case, justice - as the result of a free, albeit unexpected choice - appears to be a 'gift-value' that the more robust donor operator, sarcastically speaking, did not have to share. Therefore, it is regrettable to say that the neoclassical systems of the liberal economy often favor this reality. In this case, existing market mechanisms and legal measures are very rarely able to prevent predatory capitalism's harmful effects. However, apart from the neoclassical concept of economic liberalism, each market economy system has some imperfections and loopholes that can be used to exploit the weaker while violating the principle of social justice.

The Church's social teaching, however, has never ensured that adopting a Christian vision of morality would bring immediate positive economic effects. Economic criteria are not the only factors that should shape the methods and goals of economic activity. Economic development may periodically collide, for example, with respect for working people's rights, with the principles of social solidarity, and finally with the national raison d'état, and even be associated with a threat to the independence and sovereignty of the state. ${ }^{37}$

${ }^{34}$ Cf. S. Wyszyński, Obrona praw człowieka w świetle tajemnic żłobu betlejemskiego. Warszawa-Miodowa 28.12 .1963 [in:] id., Kazania i przemówienia autoryzowane 1956-1981, vol. ILIVII, Archiwum Instytutu Prymasowskiego w Warszawie [hereafter: KPA], vol. X, pp. 434-441.

${ }^{35}$ Id., Jakiej chcecie Polski? Do młodzieży akademickiej w Warszawie 22. 03. 1972 [in:] Nauczanie spoteczne..., p. 490.

${ }^{36}$ Id., Naród - Kościót - państwo. Kazanie świętokrzyskie 25.01.1976 [in:] Nauczanie spoteczne..., p. 707.

37 'Economics is not a god to whom man must fall to the dust. Nor is it the most important part of human life. The Christian economy is based on the "economic man" and not on things. Economic life, i.e., production and its methods, as well as goals, exchange and its paths, distribution of 
Undoubtedly, the Church's teaching does not focus on economic prosperity, which does not mean that I do not promote integral economic development. In other words, the Catholic vision of participation in socio-economic life should always be seen in the perspective of a pluralistic value system that stands ruthlessly against the concept of monistic 'economism' characteristic of many modern forms of liberal capitalism. ${ }^{38}$ Still, constructive criticism of liberal ideology seems to be a permanent feature of the Church's Catholic social teaching. Of course, its character changed radically, depending on the conditions of time and the socio-cultural context. A significant revival of the discourse on participation in socio-economic and political life took place after the Second Vatican Council (1962-1965).

No wonder, then, that Wyszyński is somewhat reserved for glorifying all manifestations of liberal capitalism in the contemporary world. In his opinion, therefore, '[...] technological progress and development should show modern man the value and meaning of the temporal world; the value of the matter hidden in the mystery of creation and the extraordinary wisdom that God reveals in the temporal world. ${ }^{39}$

From a personalistic point of view, though, economics' main task is to implement its strategic goals leading to the integral development of the entire human person - in the individual and social dimensions - as well as the satisfaction of its fundamental needs. In this sense, technological and economic advancement does not always mean progress in achieving the broadly understood human good. 'The deification of matter and production gives rise to a consumption ideal, a desire to get rich, a competitive struggle, and finally leads to the depreciation of man. ${ }^{40}$

In one of his speeches, the Primate stated:

In the world created by God, the powers of life and the seeds of various forms and figures were deposited. Therefore, its development depends on how a person responds to the values entrusted to his rational will. God does not replace man in action. Genetic forces, implanted in creation by God, constantly cooperate with man. ${ }^{41}$

social income and consumption itself, should be organized and assessed in terms of human needs, both personal and social' (id., Miłość i sprawiedliwość..., p. 320).

${ }^{38}$ Cf. Benedykt XVI, Serce rozumne. Refleksje na temat podstaw prawa, Przemówienie w Bundestagu (Berlin 22.09.2011), "L'Osservatore Romano" 10-11 (2011), p. 40.

39 S. Wyszyński, Kościót w obliczu nowej sity społecznej (Warszawa 21.05.1968) [in:] KPA, vol. XXVIII, p. 431.

${ }^{40}$ Id., Homo oeconomicus, II kazanie świętokrzyskie 20.01.1974 [in:] Nauczanie społeczne..., p. 587.

${ }^{41}$ Id., Obowiazek i prawo ludzkiej pracy. Warszawa 1.05.1971 [in:] id., „,Idzie nowych ludzi plemię...", Poznań 2001, p. 138. 
In other words, one of the weakest points of liberal capitalism is the disproportion between advanced technical and economic development and the lack of moral sensitivity and maturity of people involved in the economy. ${ }^{42}$

For this reason, the personalistic view of the human person is opposed to liberal economic systems that promote extreme consumerism and a materialistic model of culture. Although technical and industrial development seems to be very important, the most crucial goal of the Christian vision of the economy is to focus on the human person: his moral condition, responsibility for others, well-formed conscience, as well as sensitivity and conscious care for the integral development of the whole society. ${ }^{43}$

Although the capitalist economy raised great hopes and expectations at the beginning of the industrial revolution, classical capitalism did not fully live up to its hopes. The first generation of liberal capitalist adherents believed that with the formation of the free market competition system, there would be a happy era of 'perpetual' economic prosperity, affluence, and universal brotherhood. Consequently, a harmoniously balanced free market would, as it were, automatically lead to the establishment of general social justice.

However, despite many objective and unquestionable successes, including comprehensive economic development, many shortcomings of the capitalist system have been the source of harsh and ruthless criticism, especially by representatives of the Marxist-Leninist ideology. Undoubtedly, the enormous poverty of a large part of the labor world, the concentration of material goods in the hands of large monopolies, cartels, and trusts, led to a severe economic crisis, an example of which was the collapse of the stock exchange in 1929 in the largest capitalist countries of the world of the time. The stock market crisis had a 'domino effect' very quickly. Despite very optimistic predictions, it was the first half of the $19^{\text {th }}$ and the beginning of the $20^{\text {th }}$ century that the working world experienced terrible poverty and great poverty.

42 'One should be surprised - says Wyszyński - how it is possible to live an economic life in the prevailing spirit of distrust, aversion, and resistance. Therefore, care should be taken to extend the scope of cooperation between people and to establish direct contact so that relations at work become more and more human. Observance of Christian morality at work. [...] The immorality of employers and the carelessness of workers, who have bad examples in the lives of their superiors, turn the workshop into a place of constant violation of God's law. It is, therefore, necessary to overcome the breakdown of the economy and ethics, as well as the acquisition of wealth at any cost. One must strive for the returning of conscience to the factory. Finally, the preservation and protection of social legislation' (Miłość i sprawiedliwość..., pp. 383-384).

${ }^{43}$ Cf. id., Prymat osoby nad rzecza. Z okazji 30 rocznicy powstania Wydziału Filozofii Chrześcijańskiej KUL (7.03.1976) [in:] Nauczanie społeczne..., pp. 714-718; S. Świeżawski, Rola kulturotwórcza chrześcijaństwa, “Ateneum Kapłańskie” 62 (1970) 75, pp. 201-212. 


\section{5. 'Human Economy': Towards an Integrated Approach}

The distorted vision of the world and the human person not only deprive man of an essential spiritual sphere but also reduce him to the product level of the material world. It led to a distortion of human life's fundamental dimensions, preventing man from fully realizing his needs and goals. 'Nowadays, very often in various fields - states Cardinal Wyszyński - not only in the section of economic life - such a narrow understanding of man is manifested. It is governed as a commodity, material, and not as a human person, having higher tasks, reaching beyond the dimension of earthly, family, national or political life. ${ }^{34}$

The analysis of liberal capitalism in terms of Cardinal Wyszyński is not only temporary. Showing the errors existing in a given political system was primarily aimed at defining the basic principles on which Christians' involvement in the state's socio-political reality should be built. ${ }^{45}$

Of course, in his criticism of social life's liberal-capitalist model, the Primate refers to the popes' social teaching and the Church's Magisterium. It is primarily about displaying errors and systemic distortions where the fundamental ideas of the Christian vision of social and political life and the subjectivity of individual members of the state community have been negated. According to him, despite the undoubted advantages, liberal capitalism did not contribute to citizens' liberation because '[...] man is not yet respected. He is still a slave of the state, then of the matter again. Therefore, only he can respect man, and only he has a future in his hand, who can give him inner freedom. ${ }^{46}$

In the social teaching of Cardinal Wyszyński, several basic features of criticism of the capitalist system can be distinguished. It indicates the values essential for maintaining the Christian moral and social order, threatened by liberal capitalism. Among them, we can distinguish: the sphere of human rights, including

${ }^{44}$ S. Wyszyński, Duch Boży w wolnym człowieku. Podczas bierzmowania młodzieży akademickiej w Warszawie 19.05.1977 [in:] Nauczanie spoleczne..., pp. 779-780; cf. S. Jarocki, Kultura gospodarcza, “Ateneum Kapłańskie” 62 (1970) 75, pp. 240-247.

${ }^{45}$ Referring to the supporters of liberal concepts, Wyszyński stated: 'Some declare man their own god. They multiply his laws at the expense of God himself and weaker neighbors, at the expense of society and the state. Everything is to worship man. There are no restrictions here. They submit everything to the highest and irrevocable judgment of man: they proclaim his moral freedom, freedom from all social obligations. They recognize only private morality for personal use. Man can do whatever he pleases - morality is his private matter. They do the same with God. Religion is also a private matter of man. Perfection and the pursuit of God have no social significance. Man's highest goal is his temporal happiness. You can pursue this goal in all ways because here, there are no moral rules. Economics and ethics are foreign to each other. There are no higher laws, no divine commandments to which human social and economic life should be subjected' (Miłość i sprawiedliwość..., p. 46).

${ }^{46}$ Cf. id., Nasze dezyderaty. Do profesorów katolickiej nauki spotecznej (Jasna Góra, 22.01.1963) [in:] Nauczanie społeczne..., p. 197. 
the right to a decent life and responsibility for - broadly understood - social experience. However, the most severe charge against classical liberal capitalism was a misconception of the human person.

Analyzing the condition of the human person, overwhelmed by the technologized vision of the world, the Primate states:

A modern man - this fallen giant, chained in sheets of technology, technicalism, technocracy that binds him, which helps him to live and at the same time disturbs him - he must regain the freedom of God's children so that he can stand up, walk freely and fulfill the tasks assigned to him by the Creator. ${ }^{47}$

According to the Primate, one of the most severe mistakes of modern philosophy, which laid the foundations for classical liberal capitalism, is the one-sided focus on man as an individual while ignoring his personal dimension. Confusing the concepts of 'individual' and 'person' is dangerous in their social ramifications since the individual's autonomy does not yet mean the person's development as such. In this context, Cardinal Wyszyński states:

God can afford each of us to be a 'person,' a 'separate,' 'personality,' not only a numerically and statically determined individual ${ }^{48}$ In the hierarchy of values, God the Father, Creator of heaven and earth is at the forefront, then - man as a fruit of God's love, and then - the material world, which is given to man to subdue the earth. ${ }^{49}$

Thus, the human person is a central value, both on the individual and social levels. 'Man is a person. He is a rational and free being; he is the master of creation. ${ }^{50}$ However, it should be remembered that the encounter in man between the reality of the divine world and the human world takes place not directly, but in a mystery that unites and protects the human person's autonomy. 'For only a human person can make understandable any explanation of the world, because it reflects the creative wisdom of God Almighty. ${ }^{51}$

${ }^{47}$ Id., Duch Ewangelii..., p. 808.

${ }^{48}$ Id., Bóg - Człowiekiem, aby człowiek byt... Bogiem. Do inteligencji katolickiej. WarszawaMiodowa 14.01.1970 [in:] id., „Idzie nowych ludzi plemię... “. Wybór przemówień i rozważań, Poznań-Warszawa 1973, p. 48.

${ }^{49}$ Id., Najważniejsza wartościa na świecie jest czlowiek, p. 962.

${ }^{50}$ Id., Społeczność przyrodzona i nadprzyrodzona. II Konferencja Akademicka. Warszawakościót św. Anny 16.02.1957 [in:] KPA, vol. II, p. 61.

${ }^{51}$ Id., Wołanie ludzkości o obecność Kościoła w świecie współczesnym, Warszawa 26.06.1971 [in:] „Idzie nowych ludzi plemię...”, Poznań 2001, p. 93; cf. C. Bartnik, Chrześcijańska pedagogia narodowa wedtug Stefana Wyszyńskiego [in:] id., Polska teologia narodu, Lublin 1988, p. 187. 
In the Primate's opinion, economic progress conditioned by liberalism, and the classical capitalism that grew out of it, should be subject to human authority. Therefore, one cannot agree to the accumulation of vast means of production and leaving them to arbitrariness to a small group of beneficiaries of the political and economic system. According to Wyszyński,

all communities must therefore be of human measure. All of them must have as a starting point the rights and obligations of the human person to feel good in him, as in well-tailored clothing. Hence, social life forms cannot be built differently, only according to the human person's characteristics. Whenever social institutions and forms of social life collide with rights and obligations, the character and nature of the human person, they become a torment. ${ }^{52}$

Quoting the encyclical of Pius XI, Quadragesimo anno, ${ }^{53}$ the Primate states that the accumulation of wealth in the hands of a few leads to a threefold struggle: it is above all about mastering economic life itself; then, the subordination of state structures, and finally by fighting social legislation, inhibiting all pro-social reforms. This state of affairs leads to the degradation of the democratic system of social and political life and the destruction of fundamental human rights. 'No community, even the most powerful one, claims Primate Wyszyński, can violate these rights without risking conflicts with citizens, with people and their personality. In doing so, it suffers damage that threatens its own existence. ${ }^{54}$

Thus, maximum profit becomes the primary goal of any economic activity. 'Then the place of man as the subject of work is taken by capital, and the safeguarding of working human rights goes unnoticed. ${ }^{55}$ Hence, this form of capitalist liberalism causes that money, by becoming the measure of everything, to create the proletariat, a socially orphaned layer. Such a scenario of social life contributes to the creation of a system of social injustice. 'The deification of matter and production gives rise to a consumption ideal, a desire to get rich, a competitive struggle, and finally leads to the depreciation of man. ${ }^{56}$

${ }^{52}$ S. Wyszyński, „Pacem in terris”. Konferencja II. Warszawa — kościół św. Anny 27.01.1964 [in:] KPA, vol. XVI, p. 124.

${ }^{53}$ Cf. Pius XI, Quadragesimo anno (May 15, 1931), 103.

${ }^{54}$ S. Wyszyński, Homo Dei, I kazanie świętokrzyskie 13.01.1974 [in:] Nauczanie społeczne..., pp. $577-578$.

${ }_{55}$ Id., Miłość i sprawiedliwość..., pp. 247-248.

${ }^{56}$ Id., Homo oeconomicus..., p. 587. 'God has called us to work as sentient beings as Christians to help Him improve the universe; that we improve ourselves by using our talents; that we may increase the glory of God through our filial submission to his will; that we may finally show our love for God through work. This call revealed our dignity and dignity of work that does not only save the innate nature, not only tears the world out of the embrace of savagery, not only 
In other words, man, thanks to his social nature, is the beginning and end of social life. And although it needs a family, a state, cultural, religious, and economic communities for its development, it goes beyond its limits due to its unusual living structure. According to Primate Wyszyński, '[...] in our sociopolitical thinking, we must always maintain the importance of man [...]. Even if he was born in the $20^{\text {th }}$ century or the next century, he has existed in God's thoughts and plans for centuries. Therefore, it is earlier than any family, national or state community that a man has brought into existence. ${ }^{57}$

The concentration of capital and economic power in the hands of a few, which grew out of unfettered free competition, led to the struggle to subdue more and more extensive areas of economic life - and, consequently, to the control of state structures and the domination of one state over another. This state of affairs' effect was the brutalization of economic life and lowering the state's dignity and majesty. ${ }^{58}$ For selfish enrichment, various trade and industrial associations were used, which, instead of serving the common good, became a mechanism for the exploitation of individuals, classes, social strata, nations, and states. Referring to the Austrian bishops' pastoral letter from the interwar period, he states that 'Mammonist capitalism' brings deplorable results. Here the banking world is reaching in individual states, 'self-proclaimed power over state power - so that this power is no longer sovereign.' ${ }^{59}$

Primate Wyszyński, criticizing the extreme form of capitalism, states that the actual privileges and the advantage of a few over the rest of society favor the emergence of sharp class divisions and social antagonisms. Yet everyone has the right to live in dignity. He accused capitalism of the decline of morality in society. Economic living conditions can harm the moral standard of citizens. The point is that capitalism strikes at the personal dignity of the exploited worker. Then the still life leaves the workshop 'ennobled,' and the person becomes common and worse. According to the Primate, this form of capitalism lost its sensitivity to all basic human life needs and conditions. Why is this happening? Because capitalism's essence is not to meet the general public's needs but enrich individuals as much as possible. ${ }^{60}$

ennobles matter but is also the salvation and redemption of man, is his sanctification' (id., Miłość i sprawiedliwość..., pp. 355-536).

${ }^{57}$ Id., Matka - Syn - rodzina, Warszawa - kościół św. Krzyża 11.01.1976 [in:] Nauczanie spoteczne..., p. 679.

${ }^{58}$ Cf. A. Zwoliński, Ks. Stefan Wyszyński wobec kryzysu społeczno-gospodarczego Polski lat trzydziestych XX wieku, (doctoral disertation), Lublin 1990, p. 119.

59 S. Wyszyński, Miłość i sprawiedliwość..., p. 247; cf. id., Katolicyzm, kapitalizm, socjalizm. List pasterski biskupów austriackich, Lublin 1935, p. 12.

${ }^{60}$ Id., Miłość $i$ sprawiedliwość..., p. 247. To be critical of both communism and liberal capitalism is not the same as proposing by the Pope a third, so-called 'middle way'. John Paul II clearly 
Thus, the main flaw of this system is the recognition of profit as the overarching goal. If profit is the only thing that counts, all God's works disappear. For nature no longer appears as beauty, but only takes the form of raw material. The spirit of profit and the pursuit of a penny breed a hectic rush. In such an atmosphere, no one considers man's moral and religious needs, and the organization of work itself becomes an obstacle in fulfilling religious duties. Then you can lower the wages, threatening with reduction and unemployment. In this way, the goal to be pursued is to reconcile the distribution of goods with the common good and social justice principles. The exaggerated gulf between a small group of the very rich and many poor people shows a severe shortage of capitalism. ${ }^{61}$

The Christian vision of commitment to socio-economic life, embracing a mysterious synthesis of suffering and joy, reflects the age-old dichotomy of grace and sin. It becomes a dramatic struggle which, while bringing satisfaction and happiness, at the same time provides toil, torment, and suffering. Although it expresses itself in various forms, it is nevertheless an inseparable element of a human being's socio-economic activity.

Speaking about the errors and distortions of capitalism, the Primate raises the issue of social responsibility. He accuses the economic liberalism of radicalizing workers' views and thereby magnifying the influence of socialist ideology. Labor exploitation stimulated energetic individuals to seek ways out of the impasse and to remedy injustices. The 'theoretical' freedom and even the working people's political powers cannot prevent abuses by capital without courageous and determined economic reforms. ${ }^{62}$ However, in the opinion of Cardinal Wyszyński, the reform will be possible to implement meritoriously only if it would be related to morality. 'When the morality of Christian love disappears, then the love of pocket and personal gain will take first place.' ${ }^{63}$

states that ' $[\ldots]$ the Church's social doctrine is not a 'third way' between liberal capitalism and Marxist collectivism, nor even a possible alternative to other solutions less radically opposed to one another: rather, it constitutes a category of its own. Nor is it an ideology, but rather the accurate formulation of the results of a careful reflection on the complex realities of human existence, in society and in the international order, in the light of faith and of the Church's tradition. Its main aim is to interpret these realities, determining their conformity with or divergence from the lines of the Gospel teaching on man and his vocation, a vocation which is at once earthly and transcendent; its aim is thus to guide Christian behavior. It therefore belongs to the field, not of ideology, but of theology and particularly of moral theology" (John Paul II, Sollicitudo Rei Socialis, 41). Therefore, it is neither a specific political program, nor an ideology from which such a program could emerge. Instead, 'the teaching and spreading of her social doctrine are part of the Church's evangelizing mission. And since it is a doctrine aimed at guiding people's behavior, it consequently gives rise to a "commitment to justice," according to each individual's role, vocation and circumstances' (ibid., 41).

${ }^{61}$ Cf. P. Raina, Kardynat Wyszyński, vol. I, London 1979, p. 53.

${ }^{62}$ Cf. A. Zwoliński, Ks. Stefan Wyszyński, p. 120.

${ }^{63}$ Cf. S. Wyszyński, Miłość i sprawiedliwość..., p. 240. 
Capitalism without morality becomes - as the Primate noted already in the $1960 \mathrm{~s}$ - the direction of the anti-humanist economy ${ }^{64}$ Then, the only goal is to be rich. Then 'be rich at all costs - who can and as only can!' ${ }^{65}$ It must be said, however, that despite the criticism of capitalism - according to the papal encyclicals and the teaching of the Church - the Primate did not demand the complete abolition of free competition, which is one of the factors shaping economic life. The only emphasis was on allowing workers to participate in corporate management and capital to change the very nature of capitalism. 'Ultimately, the transformation of the socio-economic system depends only on the person who should focus on morality as the foundation of all activities. ${ }^{66}$

However, the most severe error of capitalism was a misunderstanding of the concept of the human person. In the classical philosophy of liberal capitalism, the individual is regarded as the only measure of everything, and his freedom is absolute and indisputable. In this way, the understood freedom of individual action tends to liberate man from all dependence. ${ }^{67}$ In this case, detached from obedience to the truth, the concept of human freedom becomes a threat to other people's rights. Then it is not easy to talk about any morality.

Thus, the freedom of the person, and therefore also freedom in the field of political and economic life, is not absolute.

Concerning the complex reality of earthly life, the only man is a person, a rational and free being. Only such a being could God speak, and only a rational and free being can understand and love God. Only God can also surround man, his work, with the fullness of his father's affection because only God is a Father for him. All others are usurpers. ${ }^{68}$

${ }^{64}$ In this context, Cardinal Wyszyński states: "God can afford to make each of us a "person," an "individuality," a "personality." Not just a kind of "separate being," numerically and statistically specified' (id., Bóg - Człowiekiem ..., p. 48). 'God the Father heads the hierarchy of values, the Creator of heaven and earth, then - man, as the fruit of God's love, and then - the temporal world, which is given to man, so that he might have dominion over it' (id., Najwazniejsza wartościa..., p. 962).

${ }^{65}$ Id., Miłość i sprawiedliwość..., p. 240.

${ }^{66}$ Id., Nasze dezyderaty..., p. 197. By taking advantage of weak individuals' vulnerability, the market of pornography, various stimulants or contraceptives, and abortion drugs are created. In this context, the Pope speaks of a 'new form of violence' to which people are subjected by 'market forces' and state institutions. In a climate of 'absolute lack of respect for the freedom of choice of the parties involved', often subject them 'to intolerable pressures [...] in order to force them to submit to this new form of oppression.' These policies are extending their field of action by the use of new techniques, to the point of poisoning the lives of millions of defenseless human beings, as if in a form of 'chemical warfare' (John Paul II, Centesimus annus, 39).

${ }^{67}$ Cf. P. Raina, Kardynat Wyszyński..., p. 58.

${ }^{68}$ S. Wyszyński, Miłość i sprawiedliwość..., p. 49. 


\section{Conclusions}

As a socio-economic thought system, the economic personalism presented by Cardinal Wyszyński is part of the Christian tradition that engages in ethical reflection on the socio-economic aspects of human life. He focuses his efforts primarily on developing and more in-depth understanding of the moral dimension of economic, political, and social human activity. It makes him vitally committed to promoting dialogue between Christian social ethics, the natural law tradition, and economics's achievements.

On this basis, economic personalism is identified with reflecting on the moral, economic, and political dilemmas that the modern world presents to man. Finally, as a philosophical position, economic personalism in Wyszyński's terms, drawing on the humanistic Christian tradition, aims to establish a free and human economy in an open and virtuous society. In this way, it becomes a bridge that allows the Christian moral tradition's intellectual resources to be transferred to the public sphere.

In the understanding of the Primate, economic personalism refers to the principle of the Church's social teaching that a person is such a good that he cannot be treated as an object of use and, in this form, as a means to an end. This principle often called the personalistic norm, is the basis of the entire moral order. Economic ethics - lest it is abstract ethics - cannot be limited to referring to this norm. It must also take into account the applicable legal system and the sociopolitical conditions that govern the economic activity of man. In this context, Cardinal Wyszyński perceives the social economy in pragmatic and praxeological terms. Without disregarding the technical aspect of economic analysis, the Primate emphasizes the systemic principles of economic life, which promote human dignity, understood as a fundamental dimension of human life and functioning.

The Christian personalist's focus, however, is not only on economics. Therefore, one has to find a specific school of economics with which one will enter into dialogue. The most frequent references are made to the work of those thinkers who have returned to the original inspiration of economics as a field belonging mainly to moral philosophy. Economic personalism, looking for a paradigm of the economy tailored to man, therefore sees in economic systems those elements that take into account and develop the Christian dimension of philosophical anthropology that perceives man as a personal being focused on integral development, both in the individual and social dimensions. Moreover, the personalistic vision of Christians' involvement in economics, as presented by Cardinal Wyszyński, is always exposed in the creative and salvific perspective of being called to participate in the supernatural reality of 'new heaven and the new earth' (cf. 2 Pt 3:13; Rev 21:1).

In this context, a critical analysis of socio-political systems is essential. Understandably, their effectiveness must take into account historical and geo-political 
circumstances. Moreover, the efficacy of political ideologies and the strategies of systemic transformation depends on social support (legitimation) and sociopolitical, economic, as well as cultural factors. Thus, if they are to be realistic and practical, new models of social life can only arise within certain specific political and historical situations. Moreover, it is possible thanks to the commitment and effort of those people who responsibly undertake to solve specific human problems, taking into account their social, economic, political, and cultural aspects, which are near related to each other.

Cardinal Wyszyński spoke in a similar vein. Although he saw the need to change public life structures, he did not consider it to be the Church's primary and immediate task. Nor did he feel that he was called to change the regime. His criticism primarily concerned the anthropological and moral dimensions of social life. The Primate was aware that if there was an appropriate moral order, then necessarily - critical elements of the state's political system would change. He has repeatedly spoken of a 'social disposition' that would favor just social transformation. In his opinion, social disposition should be based on the Christian religion's canvas, which aims to change the human heart. In this way, changed people become the right subject and base for the proper shaping of the common good.

Indicating the errors that exist in the currently functioning systems of socioeconomic life, as in the case of liberal capitalism, is primarily aimed at emphasizing, even more, the fundamental principles on which the economy and sociopolitical life should be based 'on the measure of a man.' There will probably be some shortcomings and errors in specific political and economic systems based on the assumptions of liberal capitalism, which is related to the truth that these systems and structures are created by a man marked by 'tearing' (original $\sin$ ); therefore, capable of evil. In this sense, the Church's prophetic and critical function will always be needed.

\section{Krytyka liberalnego kapitalizmu w świetle personalistycznej koncepcji życia społeczno-gospodarczego kardynała Stefana Wyszyńskiego}

\section{Streszczenie}

Przedmiotem prezentowanego artykułu jest analiza personalistycznej wizji życia społeczno-gospodarczego kardynała Stefana Wyszyńskiego w kontekście doktryny liberalnego kapitalizmu. Dokonana przez autora interpretacja materiałów źródłowych ma zatem na celu ukazanie prakseologiczno-etycznej refleksji Wyszyńskiego i umiejscowienie jej w odniesieniu do społeczno-ekonomicznych aspektów życia człowieka, charakterystycznych dla liberalnego kapitalizmu. Eks- 
ploracja powyższych badań polega na analizie tekstów źródłowych i ich reinterpretacji metodą indukcyjno-dedukcyjną. Podstawowym zaś celem badawczym powyższego artykułu jest ukazanie przesłania moralnego kardynała Wyszyńskiego w kontekście chrześcijańskiej wizji zaangażowania w życie społeczno-gospodarcze, jak również jego aplikacja do konkretnej i współczesnej rzeczywistości życia publicznego. Autor artykułu stawia pytanie, czy moralne przesłanie zawarte w personalistycznej wizji osoby ludzkiej prezentowane przez Kardynała Wyszyńskiego może być aplikowane do współczesnej rzeczywistości życia społeczno-politycznego i gospodarczego, w którym liberalny kapitalizm zdaje się dominującą ideologią świata Zachodu. Odpowiedź na tak postawione kwestie jest niezwykle istotna, zwłaszcza w kontekście odradzającego się „kolektywistycznego” populizmu, który w połączeniu z ideami tzw. „pluralizmu ideowego” podkreślającego moralną ambiwalentność „płynnej” ponowoczesności, staje się poważnym wyzwaniem nie tylko dla chrześcijaństwa, lecz także dla całego współczesnego świata.

\section{Słowa kluczowe}

liberalizm, personalizm, Kardynał Stefan Wyszyński, ekonomia, stworzenie, zbawienie, autonomia rzeczywistości ziemskiej

\section{Keywords}

liberalism, personalism, Cardinal Stefan Wyszyński, economy, creation, salvation, the autonomy of earthly reality

\section{Bibliography}

Abelshauser W., Deutsche Wirtschaftsgeschichte seit 1945, C.H. Beck, Hamburg 2004.

Altvater E., Kapitalismus, Zur Bestimmung, Abgrenzung und Dynamik einer geschichtlichen Formation, "Erwägen Wissen Ethik" 3 (2002), pp. 281-292.

Bartnik C., Chrześcijańska pedagogia narodowa wedtug Stefana Wyszyńskiego [in:] id. Polska teologia narodu, Towarzystwo Naukowe Katolickiego Uniwersytetu Lubelskiego, Lublin 1988, pp. 183-242.

Behrends S., Neue Politische Ökonomie. Systematische Darstellung und kritische Beurteilung ihrer Entwicklungslinien, Vahlen, München 2001.

Benedykt XVI, Serce rozumne. Refleksje na temat podstaw prawa, Przemówienie w Bundestagu (Berlin 22.09.2011), "L’Osservatore Romano" 10-11 (2011), p. 40.

Boettke P.J., Leeson P.T., The Austrian School of Economics 1950-2000 [in:] A Companion to the History of Economic Thought, ed. by W. Samuels, J.E. Biddle, J.B. Davis, Blackwell Publishing, Malden, MA 2003, pp. 446-452.

Cooney D.W., Distributism Basics: A Brief Introduction [in:] https://ethikapolitika.org/ 2014/08/08/distributism/.

Council of Georgist Organizations, An Introduction to Georgist Philosophy and Activity, http://www.cgocouncil.org/cwho.html. 
Czuma Ł., Dysproporcje rozwoju gospodarczego i problem ich likwidacji, "Zeszyty Naukowe Katolickiego Uniwersytetu Lubelskiego" 11 (1968) 2, pp. 53-67.

Dimand R., The origins of the Keynesian revolution, Edward Elgar Publishing Ltd, Aldershot 1988.

Emmett R.B., The Elgar Companion to the Chicago School of Economics, Elgar Publishing, Cheltenham 2010.

Ficek R., Christians in Socio-Political Life: An Applied Analysis of the Theological Anthropology of Cardinal Stefan Wyszyński, Primate of Poland, Wydawnictwo Marszałek, Toruń 2020.

Francis, Evangelii Gaudium, http:/www.vatican.va/content/francesco/en/ apost_exhortations/documents/papa-francesco_esortazione-ap_20131124_evangelii-gaudium. Html.

Galbraith J.K., Das Scheitern des Monetarismus. Von den Theorien Milton Friedmans zur Weltfinanzkrise, "Blätter für deutsche und internationale Politik" 9 (2008), pp. 69-80.

Gordon R.J., What Is New-Keynesian Economics?, "Journal of Economic Literature” 28 (1990) 3, pp. 1115-1171.

Holcombe R.G., The Median Voter Model in Public Choice Theory, "Public Choice" 61 (1989), pp. 115-125.

Jacobs L.R., King D.S., Varieties of Obamaism: Structure, Agency, and the Obama Presidency, "Perspectives on Politics" 10 (2010) 3, pp. 793-802.

Jan Paweł II, Nauczanie społeczne kościoła integralna częścia jego misji (wywiady), Fundacja Jana Pawła II. Ośrodek Dokumentacji Pontyfikatu, Rzym 1996.

Jarocki S., Kultura gospodarcza, “Ateneum Kapłańskie” 62 (1970) 75, pp. 240-247.

John Paul II, Centesimus annus, http://www.vatican.va/content/john-paul-ii/en/encyclicals/documents/hf_jp-ii_enc_01051991_centesimus-annus.html.

John Paul II, Laborem Exercens, http://w2.vatican.va/content/john-paul-ii/pl/ encyclicals/documents/hf_jp-ii_enc_14091981_laborem-exercens.html.

John Paul II, Sollicitudo rei socialis, http://www.vatican.va/content/john-paul-ii/en/encyclicals/documents/hf_jp-ii_enc_30121987_sollicitudo-rei-socialis.html.

Kapp K.W., The Foundations of Institutional Economics, Routledge, London-New York 2011.

Koppstein J., Lichbach M.I., Comparative Politics: Interests, Identities, and Institutions in a Changing Global Order, Cambridge University Press, Cambridge 2005.

Lombardini S., Ungleichheit in der Weltwirtschaftsordnung (Preise, Protektionismus, Wachstumsprozesse), "Concilium” 16 (1980) 12, pp. 676-681.

Nauczanie społeczne 1946-1981, red. M. Płaskacz i in., ODiSS, Warszawa 1990.

Perkins H., Confession of an Economic Hit Man, Berret-Koehler, San Francisco 2004.

Perry M.J., It's the Greatest Achievement in Human History, and One You Probably Never Heard About, American Enterprise Institute, November 3, 2014, www.aei.org/ publication/greatest — achievement-human-history-one-probably-never-heard/.

Pipes R., Property and Freedom, Vintage, New York 2000. 
Pius XI, Quadragesimo anno (May 15, 1931), http://w2.vatican.va /content/pius-xi/en/ encyclicals/documents/hf_pxi_enc_19310515_quadragesimo-anno.html.

Raina P., Kardynat Wyszyński, vol. I, Publishing House of Poets and Painters, London 1979.

Scruton R., Słownik myśli politycznej, Zysk i S-ka Wydawnictwo, Poznań 2002, pp. 190191.

Sen A.K., Poverty and Famines: An Essay on Entitlement and Deprivation, Oxford University Press, Oxford 1981.

Small G., Connecting Economics to Theology, "Solidarity: The Journal of Catholic Social Thought and Secular Ethics" 1 (2011) 1, pp. 1-2.

Small G., Property, Commerce and Living God's Will, "Journal of Interdisciplinary Studies" 16 (2004) 1-2, pp. 157-172.

Sternberg E., Defining Capitalism, "Economic Affairs" 35 (2015) 3, pp. 380-396.

Świeżawski S., Rola kulturotwórcza chrześcijaństwa, “Ateneum Kapłańskie” 62 (1970) 75, pp. 201-212.

Varloot J., Vrai ou faux ami? L'original des Eleuthéromanes, "Recherches sur Diderot et sur l'Encyclopédie" 10 (1991), pp. 9-22.

Weber M., The Protestant Ethic and the Spirit of Capitalism, Merchant Books, New York 2003.

Wilberg P., Deep Socialism: A New Manifesto of Marxist Ethics and Economics, New Gnosis Publications, London 2003.

Winters J.A., Page B.I., Oligarchy in the United States? "Perspectives on Politics" 7 (2009) 4, pp. 731-751.

Wyszyński S., Bóg - Człowiekiem, aby człowiek był... Bogiem. Do inteligencji katolickiej. Warszawa-Miodowa 14.01.1970 [in:] „Idzie nowych ludzi plemię... “. Wybór przemówień i rozważań, Pallotinum, Poznań-Warszawa 1973, pp. 46-50.

Wyszyński S., Czas to miłość. Podczas uroczystości Wniebowzięcia Matki Bożej (Jasna Góra, 15.08.1979) [in:] Nauczanie społeczne..., pp. 888-892.

Wyszyński S., Duch Boży w wolnym człowieku. Podczas bierzmowania młodzieży akademickiej w Warszawie 19.05.1977 [in:] Nauczanie społeczne..., pp. 778-782.

Wyszyński S., Duch Ewangelii worganizacji życia społeczno-zawodowego i publicznego w Polsce. Do wiernych w archikatedrze warszawskiej 6.01.1978 [in:] Nauczanie społeczne..., pp. 801-809.

Wyszyński S., Homo Dei, I kazanie świętokrzyskie 13.01.1974 [in:] Nauczanie spoteczne..., pp. 574-580.

Wyszyński S., Homo oeconomicus, II kazanie świętokrzyskie 20.01.1974 [in:] Nauczanie społeczne..., pp. 581-588.

Wyszyński S., In principio erat Verbum... W600-lecie powstania Uniwersytetu Jagiellońskiego. Kraków - kościół św. Anny 5.09.1964 [in:] id., Z rozważań nad kultura ojczysta, Pallottinum, Warszawa-Poznań 1979, pp. 56-68. 
Wyszyński S., Jakiej chcecie Polski? Do młodzieży akademickiej w Warszawie 22.03.1972 [in:] Nauczanie spoleczne..., pp. 488-493.

Wyszyński S., Kamienie węgielne budowania na górach świętych (Jasna Góra 2.11.1956) [in:] Wielka Nowenna Tysiaclecia, Société d'éditions internationales, Paryż 1962, pp. 37-49.

Wyszyński S., Katolicyzm, kapitalizm, socjalizm. List pasterski biskupów austriackich, Lublin 1935.

Wyszyński S., Kościót jest najlepszym sprzymierzeńcem waszych dążeń. Do NSZZ „, Solidarnośc” regionu Wielkopolska (Gniezno 4.02.1981) [in:] Do „,Solidarności”, Editions Spotkania, Warszawa 1996, pp. 47-56.

Wyszyński S., Kościól wobliczu nowej sity społecznej (Warszawa 21.05.1968) [in:] Kazania i przemówienia autoryzowane 1956-1981, t. I-LIVII. Archiwum Instytutu Prymasowskiego w Warszawie [hereafter: KPA], t. XXVIII, pp. 429-435.

Wyszyński S., Matka - Syn - rodzina. Warszawa - kościół św. Krzyża 11.01.1976 [in:] Nauczanie spoleczne..., pp. 676-683.

Wyszyński S., Miłość i sprawiedliwość społeczna. Rozważania społeczne, Pallotinum, Poznań 1993.

Wyszyński S., Moc żywej wiary w ciężkiej sytuacji Kościoła. Do duchowieństwa w Gdańsku 23.11.1960 [in:] Nauczanie społeczne..., pp. 161-167.

Wyszyński S., Najważniejsza wartościa na świecie jest człowiek. Do delegacji NSZZ „Solidarność” Region Mazowsze 19.10.1980 [in:] Nauczanie społeczne..., pp. 960965.

Wyszyński S., Naród - Kościót - Państwo. Kazanie świętokrzyskie 25.01.1976 [in:] Nauczanie spoteczne..., pp. 705-713.

Wyszyński S., Nasze dezyderaty. Do profesorów katolickiej nauki społecznej. Jasna Góra 22.01.1963 [in:] Nauczanie społeczne..., pp. 195-200.

Wyszyński S., Obrona praw człowieka w świetle tajemnic żłobu betlejemskiego. Warszawa-Miodowa 28.12.1963 [in:] KPA, t. X, pp. 434-441.

Wyszyński S., Obowiazek i prawo ludzkiej pracy. Warszawa 1.05.1971 [in:] id., „Idzie nowych ludzi plemię...”, Pallotinum, Poznań 2001, pp. 138-144.

Wyszyński S., O katolickiej woli życia. List pasterski na Wielkanoc 1947 [in:] Nauczanie społeczne..., pp. 29-40.

Wyszyński S., „Pacem in terris”. Konferencja II. Warszawa-kościót św. Anny 27.01.1964 [in:] KPA, t. XVI, pp. 122-129.

Wyszyński S., Problem pracy górników w Polsce. List do księdza biskupa Herberta Bednorza (2.02.1978) [in:] Nauczanie społeczne..., pp. 810-814.

Wyszyński S., Prymat osoby nad rzecza. Z okazji 30 rocznicy powstania Wydziatu Filozofii Chrześcijańskiej KUL (7.03.1976) [in:] Nauczanie społeczne..., pp. 714-718.

Wyszyński S., Społeczność przyrodzona i nadprzyrodzona. II Konferencja Akademicka. Warszawa - kościót św. Anny 16.02.1957 [in:] KPA, t. II, pp. 57-79. 
Wyszyński S., Wołanie ludzkości o obecność Kościoła w świecie wspótczesnym, Warszawa 26.06.1971 [in:] „Idzie nowych ludzi plemię...”, Pallotinum, Poznań 2001, pp. 91-98.

Wyszyński S., Wyzwalanie wspótczesnych niewolników. Do dziekanów archidiecezji warszawskiej 24.09.1980 [in:] Nauczanie społeczne..., pp. 955-959.

Zwoliński A., Ks. Stefan Wyszyński wobec kryzysu społeczno-gospodarczego Polski lat trzydziestych XX wieku, (doctoral disertation) Biblioteka KUL, Lublin 1990. 